\title{
A Review of the Environmental Trigger and Transmission Components for Prediction of Cholera
}

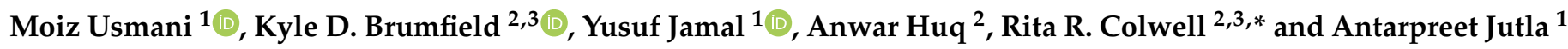 \\ 1 Geohealth and Hydrology Laboratory, Department of Environmental Engineering Sciences, \\ University of Florida, Gainesville, FL 32603, USA; moiz.usmani@ufl.edu (M.U.); yjamal@ufl.edu (Y.J.); \\ antar.jutla@essie.ufl.edu (A.J.) \\ 2 Maryland Pathogen Research Institute, University of Maryland, College Park, MD 20742, USA; \\ kbrum@umd.edu (K.D.B.); huq@umd.edu (A.H.) \\ 3 University of Maryland Institute for Advanced Computer Studies, University of Maryland, \\ College Park, MD 20742, USA \\ * Correspondence: rcolwell@umd.edu
}

Citation: Usmani, M.; Brumfield, K.D.; Jamal, Y.; Huq, A.; Colwell, R.R.; Jutla, A. A Review of the Environmental Trigger and Transmission Components for Prediction of Cholera. Trop. Med. Infect. Dis. 2021, 6, 147. https:// doi.org/10.3390/tropicalmed6030147

Academic Editor: David Nalin

Received: 14 June 2021

Accepted: 31 July 2021

Published: 5 August 2021

Publisher's Note: MDPI stays neutral with regard to jurisdictional claims in published maps and institutional affiliations.

Copyright: (c) 2021 by the authors. Licensee MDPI, Basel, Switzerland. This article is an open access article distributed under the terms and conditions of the Creative Commons Attribution (CC BY) license (https:// creativecommons.org/licenses/by/ $4.0 /)$.

\begin{abstract}
Climate variables influence the occurrence, growth, and distribution of Vibrio cholerae in the aquatic environment. Together with socio-economic factors, these variables affect the incidence and intensity of cholera outbreaks. The current pandemic of cholera began in the 1960s, and millions of cholera cases are reported each year globally. Hence, cholera remains a significant health challenge, notably where human vulnerability intersects with changes in hydrological and environmental processes. Cholera outbreaks may be epidemic or endemic, the mode of which is governed by trigger and transmission components that control the outbreak and spread of the disease, respectively. Traditional cholera risk assessment models, namely compartmental susceptible-exposed-infectedrecovered (SEIR) type models, have been used to determine the predictive spread of cholera through the fecal-oral route in human populations. However, these models often fail to capture modes of infection via indirect routes, such as pathogen movement in the environment and heterogeneities relevant to disease transmission. Conversely, other models that rely solely on variability of selected environmental factors (i.e., examine only triggers) have accomplished real-time outbreak prediction but fail to capture the transmission of cholera within impacted populations. Since the mode of cholera outbreaks can transition from epidemic to endemic, a comprehensive transmission model is needed to achieve timely and reliable prediction with respect to quantitative environmental risk. Here, we discuss progression of the trigger module associated with both epidemic and endemic cholera, in the context of the autochthonous aquatic nature of the causative agent of cholera, $V$. cholerae, as well as disease prediction.
\end{abstract}

Keywords: environmental parameters; cholera; Vibrio cholerae; trigger; transmission; prediction

\section{Introduction}

Cholera is transmitted primarily by ingestion of contaminated water containing the bacterium Vibrio cholerae and has plagued the world for centuries. The ongoing cholera pandemic, the seventh, which started in the 1960s, continues to claim millions of victims every year and is considered the world's longest-running pandemic [1-3].This acute diarrheal disease remains one of the most significant public health burdens in many regions globally, notably in Latin America, sub-Saharan Africa, and Southern Asia [4,5], where an estimated one million cases are reported every year [6]. The World Health Organization estimates that up to four million reported cholera cases occur across the world annually [4]. However, the actual number of cholera cases is likely much higher as many cases go unreported, especially in developing countries.

In recent years, cholera outbreaks have originated primarily in coastal areas $[7,8]$. The disease is prevalent in parts of the world where human vulnerability (i.e., lack of 
access to clean water and appropriate sanitation) intersects with changes in hydrological and environmental processes, which provide conditions favorable for the occurrence and growth of $V$. cholerae in the aquatic environment. Furthermore, massive cholera outbreaks are often associated with natural and anthropogenic disasters. A recent example is one of the largest cholera outbreaks in 2016 during the months following Hurricane Matthew [9], which lashed rains over the southwestern coast of Haiti. Damage to water, sanitation, and hygiene (WASH) infrastructure coupled with elevated air temperatures and above-average rainfall promoted exposure of the population to contaminated water. An outbreak of cholera was reported subsequently.

Throughout history, during periods of active conflict and raging wars, infectious diseases have claimed more lives than actual war-induced injuries [10]. Since March 2015, Yemen, a coastal Middle Eastern country, has experienced surges of violent civil unrest. In October 2016, Yemen reported the first of a series of sporadic cholera outbreaks. After the initial reports, the number of cases declined briefly for a few months until the WASH infrastructure failed, resulting in a severe spike in the number of reported cholera cases. The resurgence of the disease and continued environmental exposure of the population proved disastrous to public health. By the end of 2017, Yemen was experiencing the largest cholera outbreak in recorded history [11], which ultimately accounted for an estimated $80 \%$ of the globally reported cholera cases that had been recorded since 2015 [12]. While natural disasters can be catalytic for cholera, the Yemen cholera outbreak demonstrates the enormous potential for an anthropogenic catastrophe to affect public health similarly and perhaps even more devastatingly.

Cholera occurs predominantly in two forms: epidemic, characterized either by the sporadic or rampant occurrence of cases in an outbreak; and endemic, defined as cases occurring annually at a continuous level, often with distinct seasonal peaks in the number of cases. Data from epidemiological surveillance suggest that the Yemen cholera outbreak began in the epidemic mode [13]. The dominant hypothesis for epidemic cholera is related to conditions when the air temperature is suddenly anomalously high and excess rainfall occurs with insufficient and/or damaged WASH infrastructure in the region. Human populations will then be at higher risk of exposure to cholera bacteria, hence the disease $[14,15]$. Per contra, endemic cholera has been shown to occur in a region where $V$. cholerae is constant, even at low abundance, and circulating in the aquatic environment (e.g., rivers, estuaries, and coastal aquatic ecosystems providing conditions favorable for the bacterium). Often, environmental factors influencing endemic cholera will result in cyclical or seasonal recurrence of the disease [16,17]. A sustained epidemic mode of cholera can evolve to become endemic in regions, with the potential for enhanced and continued exposure to, and transmission of, V. cholerae [18]. From our previous research [2,19-23], it is understood that $V$. cholerae ecology must be viewed in the context of its natural aquatic environment and a changing climate driving cholera as a potential re-emerging infectious disease.

The dominant forms of cholera (epidemic and endemic) are guided by two components that are key to a disease outbreak, namely trigger and transmission. The trigger module (TM) comprises those mechanisms that support the growth, multiplication, persistence, and distribution of $V$. cholerae in the environment. That is, when TM indicates conditions are favorable for the high abundance of the bacterium and is coincident with insufficient WASH infrastructure, there will be increased interaction between $V$. cholerae and the human population. Following a prevailing TM, the transmission component (TrM) comprises pathways by which an outbreak of cholera will occur and engages complex interactions between humans and contaminated water. The foundational theory of TrM is that humans can accelerate the spread of cholera via intestinal colonization and shedding of cholera bacteria into the environment, thereby contaminating drinking water systems [18]. Given favorable environmental conditions, the bacterium multiplies and can infect a population through the fecal-environmental-oral transmission route. Here, we discuss progression of the TM underlying epidemic cholera, and the TrM associated with both epidemic and 
endemic cholera, in the context of $V$. cholerae as a bacterium autochthonous to the aquatic habitat and prediction of cholera in the human population.

\section{Vibrio cholerae and Its Natural Habitat}

Vibrio cholerae, the causative agent of the acute diarrheal disease cholera, is a Gramnegative bacterium native to the aquatic environment. Historically, detection of $V$. cholerae was achieved by determining its presence clinically during cholera outbreaks [24]. However, before the advent of epifluorescent microscopy [25,26] and molecular markers [27-31], detection of the presence of $V$. cholerae in the environment was accomplished by employing culture-based techniques [32]. Such investigations significantly underestimated $V$. cholerae populations in the environment, namely because the bacterium can enter a viable but non-culturable (VBNC) state [33]. In the environment and between outbreaks, when environmental conditions are unfavorable for growth and reproduction, the VBNC state allows the bacterium to become metabolically dormant $[34,35]$. When environmental conditions again become favorable, VBNC cells regain cultivability, having retained virulence potential $[36,37]$. Furthermore, $V$. cholerae attaches to zooplankton by switching from motile to biofilm lifestyles, which enhances long-term survivability of the bacterium in the environment [38]. Zooplankton, namely copepods, feed on components of the phytoplankton population. Hence, an association between the occurrence of copepods and phytoplankton blooms has been observed [19]. In nutrient-rich water, the increase in the phytoplankton population followed by a zooplankton bloom results in an abundance of $V$. cholerae in coastal waters [16,22]. Because a single copepod can carry up to $10^{4} \mathrm{~V}$. cholerae cells $[19,39]$, ingestion of untreated drinking water containing a small number of copepods can increase the risk of infection significantly [40-42]. Thus, copepods are a major host and vector of disease. $V$. cholerae has also been observed at high densities attached to abiotic substrates, such as sediment, and associated with various aquatic organisms (e.g., crustaceans, arthropods, fishes, waterfowl, and aquatic plants) [20]. Conversely, in the environment, $V$. cholerae, in association with phages and protozoa, can form antagonistic relationships that reduce microbial populations and shape evolution [20,43].

$V$. cholerae shares many genotypic and phenotypic characteristics with other bacterial taxa, namely Enterobacteriaceae, and toxigenic strains of $V$. cholerae have acquired the ability to produce cholera toxin, a primary virulence factor, via horizontal gene transfer mediated by a lysogenic bacteriophage [44]. The presence and broad distribution of its virulence genes in the environment have been well documented, and such genes that play a role in the pathogenicity of $V$. cholerae for humans may, at the same time, have environmental relevance (e.g., allowing for metabolic processes, establishing symbiosis, and/or modulating predator/prey relationships in the natural aquatic environment) [45-47]. In the environment, novel phylogenetic lineages of $V$. cholerae have emerged, carrying mutations potentially involved in adapting to aquatic ecosystems [48-50]. Environmental factors, such as the presence of chitin and/or nutrient limitation, can influence horizontal gene transfer [51]. Because many environmental $V$. cholerae isolates have been shown to encode various virulence factors [52] and genetic mutations, some of which have the potential to alter virulence factor production [53], horizontally acquire additional pathogenicity genes [54,55], and even undergo serogroup conversion [55], it is important to determine the total number of $V$. cholerae present in given samples.

Changes in the aquatic environment can have an impact on the intensity of a cholera outbreak [2,23,56-58], and seasonal outbreaks occur annually in regions where the disease is endemic [16,17,59-61]. During outbreaks, the reported number of cholera cases generally peaks during warmer months of the year, notably in Latin America and Africa, but bi-modal peaks are typical in the Bengal Delta region, related to the hydroclimatic influence on the environment in which the bacterium occurs [62]. In Northern Europe and the Atlantic coast of the United States, heatwaves and warming sea temperatures (up to $\sim 1.5^{\circ} \mathrm{C}$ over the past half-century) have been associated with long-term increases in abundance of certain pathogenic Vibrio spp., namely V. cholerae, V. parahaemolyticus, and V. vulnificus [21]. While it 
is worth noting that other Vibrio spp., such as Vibrio splendidus, express virulence factors at low temperatures [63], observed increases in Vibrio spp. abundance in Northern Europe and the US were associated with an unprecedented occurrence of environmentally acquired Vibrio infections in the human population [21]. Moreover, a changing climate, namely increased sea temperature, could lead to prolonged seasonal abundance of $V$. cholerae, with profound public health implications [64].

Since $V$. cholerae is autochthonous to the aquatic environment, playing an essential role in nutrient cycling $[65,66]$, cholera cannot be eradicated. Therefore, the ecology of $V$. cholerae must be understood in terms of those environmental parameters that drive cholera, especially as a re-emerging infectious disease and in constructing risk prediction models. Furthermore, early warning systems will be needed to safeguard public health in geographical regions vulnerable to natural disasters such as hurricanes and earthquakes or active conflict, namely social strife or civil war, with resultant damage to safe water and sanitation infrastructure.

\section{Trigger and Transmission Components for Prediction of Cholera}

Traditionally, the spread of cholera has been associated with human activity, notably travel [24] and not hydroclimatic processes. Hydroclimatic processes control the distribution, growth, and incidence of $V$. cholerae in aquatic ecosystems [2] and contribute to genetic diversity and epidemic potential [48]. Therefore, the spread of cholera is a complex function of global travel coupled with climatic processes and the subsequent potential exposure of populations to new spatial and temporal disease outbreaks. Thus, epidemiological research can improve public health interventions aimed at controlling cholera by employing environmental predictive modeling. In 1996, Colwell [2] reported that environmental variables were linked to cholera epidemics and could be evaluated using remote sensing and utilized to develop predictive cholera models. Subsequently, several investigators have confirmed the association of $V$. cholerae with environmental parameters, including sea surface temperature [67-69], sea surface height [67-69], chlorophyll [23,68,70], precipitation [14,71,72], water storage [73], and salinity [74,75], and suggested their use in cholera risk prediction. Accordingly, a mechanistic understanding of environmental factors in the trigger and transmission of cholera has been developed $[9,15,76]$. While both TM and TrM are important in understanding the global persistence of cholera, high mortality rates observed in epidemic regions $(>3 \%)$ compared to the endemic areas $(<1 \%)$ [15] have caused intervention efforts to focus essentially on the TM of predictive cholera modeling systems.

In 2013, Jutla et al. [15] proposed the hypothesis for an epidemic cholera trigger risk prediction system whereby anomalously high (defined as more than one standard positive deviation above the long-term average ( $>30$ years)) temperatures followed by anomalously high precipitation, over a period of four weeks, in a region of damaged or compromised WASH infrastructure, facilitated interaction between contaminated water and the human population and comprised an environment favorable for triggering an epidemic cholera outbreak. With this hypothesis, if one or more of the respective conditions are not satisfied, the region has a lower risk of experiencing an outbreak. Initial support of this hypothesis was obtained from analysis of an earthquake that struck Nepal in 2015 [76], and the hypothesis was validated spatially and temporally for several geographic regions, including South Sudan, Cameroon, Zimbabwe, Haiti, Mozambique, Rwanda, Central African Republic, Nepal, and Bangladesh [9,14,15,70,76] Subsequently, the hypothesis was extended to predict the impact of a disaster (natural or anthropogenic) in triggering a cholera outbreak $[9,76]$. Results showed that natural and anthropogenic disasters that damaged WASH facilities in a region were generally accompanied by high precipitation, collectively making the environment strongly favorable for the growth of $V$. cholerae and increasing human interaction with contaminated water sources. Thus, policy makers and health professionals are now able to use predictive environmental TMs as a tool to prevent, control, and eliminate cholera. It is worth noting, however, that once an outbreak occurs, the TM should be employed in conjunction with TrM to fully capture the progression of cholera 
in a given region. The transmission component is more broadly useful compared to the TM since TrM largely relates to the mechanism governing the disease dynamics in a human population and is often employed for forecasting the spread of cholera and public health decision-making $[77,78]$. Many modeling efforts have been made to reduce the disparity between the actual number of cases in a region and the number predicted by the model (i.e., the forecasted number of cases) $[72,79,80]$. The compartmental model is the most common type of TrM, mainly because it is simple and easy to use [81]. Compartmental models generally divide a given population into three compartments: Susceptible (S), Exposed (E)/Infected (I), and Recovered (R). The four compartments collectively comprise the basic SEIR transmission model [18], a frequently used approach in the epidemiological research domain. Typically, disease dynamics are captured by the rates at which individuals of a population transition between each state (i.e., S, E, I, and R). In Figure 1, we extend the presentation of a basic SIR model to S-E-I-R, accounting for the pathway between the susceptible and exposed populations that have the potential to become infected.

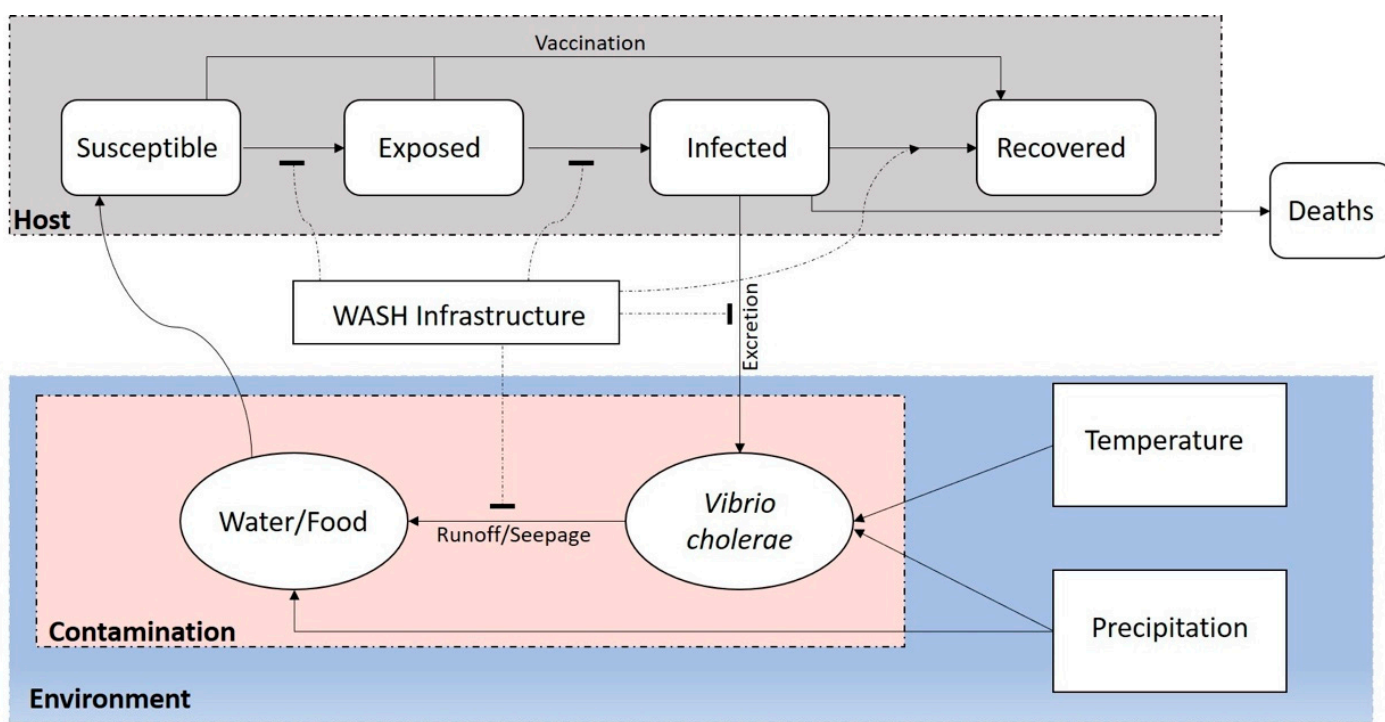

Figure 1. Fundamental cholera susceptible-exposed-infected-recovered (SEIR) transmission model. Susceptible (S) individuals of a population who have been exposed to Vibrio cholerae have the potential to acquire the disease from infected (I) individuals. At that point, they also have the potential to become infected (i.e., enter the infectious state), until eventual recovery from the disease (R) or death. Grey shading depicts the SEIR model, which also highlights the potential use of vaccines in curtailing the disease. Water, sanitation, and hygiene (WASH) infrastructure is a critical factor influencing cholera transmission at every stage of the model, from infected to susceptible individuals. Blue represents environmental factors, namely temperature and precipitation, that promote the growth and distribution of Vibrio cholerae, the causative agent of cholera, in aquatic reservoirs. Pink shows the potential transmission route from the environment to humans via contaminated food or water containing the $V$. cholerae. Arrow: positive effect; block: negative effect.

The fundamental theory of the SEIR model is presented as the simultaneous presence of four entities (i.e., S, E, I, and R) required for a cholera outbreak. That is, there must be a sufficient quantity of $V$. cholerae circulating within a population, including a large enough number of susceptible individuals. If any of the four entities is missing, the number of cases in an outbreak is reduced, thereby preventing a sporadic outbreak from becoming epidemic in scale. With respect to the dynamics of cholera, there are cyclic interactions between the human population and the pathogen. The robustness of an SEIR-based TrM relies heavily on the extent to which the module is capable of capturing the interactions. Accordingly, a number of studies have employed various mathematical and biological concepts to modify the basic SEIR model in order to incorporate complex interactions associated with modeling cholera outbreaks [82-85]. Table 1 summarizes a few key studies utilizing the SEIR model in cholera outbreaks. 
More sophisticated SEIR modeling concepts have been proposed with varying constraints of population structure [86], socio-economic factors [86,87], and other critical factors relevant to the transmission dynamics of cholera. Primarily, mathematical sophistication introduced into a SEIR model aims to address the environmental, biological, and behavioral stochasticity inherent in the mechanism of cholera transmission [56]

However, in some cases, rigorous mathematical complexity may impart problems in evaluating the success of intervention strategies and in assessing the effectiveness of behavioral changes in the human population [80]. In contrast, assumptions made to reduce complexity bring major drawbacks also introduce uncertainty, with respect to overall predictive power. Infection with $V$. cholerae $\mathrm{O} 1$, the primary pandemic serogroup, results in protective immunity (i.e., vibriocidal antibodies) that decrease the risk of future infection [88]. Modeling cholera vaccines usually require an assumption that vaccinated individuals share the same protective rate as those naturally infected, and therefore the vaccinated susceptible individuals are treated as 'resistant' [89]. Age has been shown to be important, as children under the age of 5 and the elderly have the highest disease burden of cholera $[90,91]$, but models typically assume that the population age is constant. Attempts to integrate human behavior into the SEIR model typically include the assumption that humans will behave rationally in response to the disease [83]. In practice, this assumption requires the susceptible population to be adequately informed regarding the severity of the cholera outbreak, take necessary measures to reduce contact with contaminated water/food, such as boiling or filtering water, cleaning food preparation areas, and cooking food (especially seafood) properly, and exercise appropriate sanitation practices, including the appropriate disposal of excreta. The assumption of rationality is associated with SEIR models, but it is challenging to quantify the inherent characteristics of human behavior to achieve a realistic representation of the human component in the model. While this assumption eases the model sophistication, it fails to capture the heterogeneities of cholera transmission, increasing the difference between reality and model prediction [80]. Moreover, elucidation of the human factor in cholera modeling is aggravated by the assumption that the mixing of susceptible and infectious individuals will be homogeneous. However, in reality, it has been observed that individuals move within a strong influence of socioeconomic factors [92-94]. Hence, various methods have been used to avoid the problematic assumption of homogenous mixing, which includes dividing the susceptible population into low- and high-risk groups or into various categories, based on age, neighborhood, and behavioral risk $[86,95]$. In addition to these factors, education is considered to be the most cost-effective intervention strategy to prevent the transmission of cholera within at-risk populations [96].

While these methods help to improve the prediction of cholera transmission within well-mixed populations, they fail to capture cholera modes of infection via indirect routes, such as pathogen movement via the environment, or heterogeneities relevant to disease transmission. Interaction between environment and humans is of paramount importance for predictive modeling of cholera [87]. Traditional SEIR models are less successful in dealing with indirect modes of cholera transmission, most likely explaining why they are successful in predicting highly infectious human pathogen spread via direct human-tohuman contact (e.g., for viruses causing influenza and coronavirus disease 2019, COVID-19) compared to cholera, where indirect transmission plays a more important role [80]. The importance of indirect transmission routes has encouraged the incorporation of water quality models, seasonality, and climate-driven concepts into SEIR models [58,97-100]. Seasonality is more often analyzed in regions prone to flooding after heavy precipitation, such as Bangladesh [57] and Yemen [101], where monsoons promote a bimodal peak of reported cholera cases $[13,17]$. The integration of environmental variables into SEIR models will therefore be expected to yield better performance. Given the complex nature of $V$. cholerae in the aquatic environment, an individual environmental variable is insufficient to capture the indirect mode of cholera transmission. That is, to understand the complete dynamics of a cholera outbreak, predictive models need to capture both the direct, namely pathogen 
movement via humans, and indirect transmission routes. In contrast to SEIR models, models relying solely on the variability of environmental factors have shown remarkable success in real-time cholera prediction [102], suggesting that indirect transmission routes also must be monitored. Furthermore, sensitivity analysis has shown parameter uncertainty in SEIR models, implying small uncertainties in the model parameters (e.g., infection rate) may result in large variations in overall performance $[80,103]$. Due to parameter uncertainties with respect to cholera and an inability to incorporate indirect transmission routes, SEIR models have been less successful in modeling cholera than other infectious diseases.

Table 1. Cholera prediction using variants of susceptible-infectious-recovered models.

\begin{tabular}{|c|c|c|}
\hline Author(s) & Study Descriptions/Methodology & Important Findings and Outcomes \\
\hline Codeço 2001 [18] & $\begin{array}{l}\text { Proposed mathematical model to explain the } \\
\text { dynamics of epidemic and endemic cholera. } \\
\text { This study is one of the first applications of } \\
\text { the SIR model for cholera transmission. }\end{array}$ & $\begin{array}{l}\text { - Cholera epidemiology depends on social and } \\
\text { environmental factors. } \\
\text { - Complex interaction between host and } \\
\text { pathogen is difficult to model. }\end{array}$ \\
\hline Wang et al., 2015 [83] & $\begin{array}{l}\text { Separated ordinary differential equation } \\
\text { (ODE) and reaction-convection-diffusion } \\
\text { partial differential equation (PDE) models to } \\
\text { examine the homogeneous and } \\
\text { heterogeneous environments associated with } \\
\text { cholera transmission. }\end{array}$ & $\begin{array}{l}\text { Basic reproduction number }\left(\mathrm{R}_{0}\right) \text { remains a } \\
\text { sharp threshold for disease dynamics even } \\
\text { when human behavior is considered. } \\
\text { Proposed mathematical justification of several } \\
\text { consequences associated with human behavior. }\end{array}$ \\
\hline Meszaros et al., 2020 [84] & $\begin{array}{l}\text { Proposed a mathematical model for cholera } \\
\text { incorporating transmission within and } \\
\text { between households. }\end{array}$ & $\begin{array}{l}\text { Vaccine interventions appeared more effective } \\
\text { than water treatment or antibiotic } \\
\text { administration to control household cholera. }\end{array}$ \\
\hline Abrams et al., 2013 [85] & $\begin{array}{l}\text { Developed three cholera surveillance models } \\
\text { to forecast the expected number of cases in } \\
\text { Haiti during the 2010-2011 cholera epidemic. }\end{array}$ & $\begin{array}{l}\text { - Models increased in complexity as more } \\
\text { information became available: first projection } \\
\text { estimated 105,000 cholera cases the first year; } \\
\text { subsequent projections using different methods } \\
\text { estimated up to } 652,000 \text { cases. } \\
\text { Timely and realistic projections are crucial in } \\
\text { areas with limited resources: real-time } \\
\text { projections allowed public health officials to } \\
\text { plan and implement response measures better. }\end{array}$ \\
\hline Torres et al., 2018 [82] & $\begin{array}{l}\text { Proposed and analyzed a SITRV (susceptible- } \\
\text { infectious-treated-recovered-vaccinated) type } \\
\text { model for cholera. }\end{array}$ & $\begin{array}{l}\text { - The SITRV type model fits well for the cholera } \\
\text { outbreak in Yemen April 2017-2018. } \\
\text { The model provides important conclusions } \\
\text { concerning vaccination campaigns during a } \\
\text { cholera outbreak. }\end{array}$ \\
\hline Che et al., 2020 [86] & $\begin{array}{l}\text { Used a "fitted" demographic equation (i.e., } \\
\text { disease-free equation) to capture total } \\
\text { population and a fitted low-high risk } \\
\text { structured cholera differential equation } \\
\text { model to study reported cholera cases in } \\
\text { Cameroon 1987-2004. }\end{array}$ & $\begin{array}{l}\text { - Dual strategies of either vaccination and } \\
\text { treatment or vaccination and improved } \\
\text { sanitation or combined strategy of vaccination, } \\
\text { treatment, and improved sanitation reduce the } \\
\text { basic reproductive number of cholera cases. } \\
\text { Rates of scaled contact and the vaccination of } \\
\text { susceptible populations are important } \\
\text { parameters for cholera prediction. }\end{array}$ \\
\hline
\end{tabular}


Table 1. Cont.

\begin{tabular}{|c|c|c|}
\hline Author(s) & Study Descriptions/Methodology & Important Findings and Outcomes \\
\hline Dangbé et al., 2018 [87] & $\begin{array}{l}\text { Proposed a model considering climatic } \\
\text { factors and human behavior on the spread of } \\
\text { cholera }\end{array}$ & $\begin{array}{l}\text { - The transmission and spread of cholera can be } \\
\text { affected by climatic factors, the proportion of } \\
\text { malnourished individuals, and the number of } \\
\text { individuals practicing proper hygiene. } \\
\text { Disease-free equilibrium stability depends on } \\
\text { the basic reproduction number }\left(\mathrm{R}_{0}\right) \text {. }\end{array}$ \\
\hline Baracchini et al., 2017 [56] & $\begin{array}{l}\text { Proposed a stochastic, rainfall-temperature } \\
\text { driven model to examine the seasonality of } \\
\text { cholera in Bangladesh. }\end{array}$ & $\begin{array}{l}\text { - Rainfall buffers disease transmission in wet } \\
\text { regions while enhancing cholera resurgence in } \\
\text { dry regions. } \\
\text { Local variation of temperature and rainfall can } \\
\text { be used to explain seasonal patterns. }\end{array}$ \\
\hline Koepke et al., 2016 [97] & $\begin{array}{l}\text { Proposed a predictive } \\
\text { 'susceptible-infected-recovered-susceptible' } \\
\text { (SIRS) type model in the form of } \\
\text { continuous-time hidden Markov states to } \\
\text { estimate the contribution of water depth and } \\
\text { water temperature on the spread of cholera. }\end{array}$ & $\begin{array}{l}\text { - Hidden states can be used to predict an } \\
\text { increase in infected individuals weeks before } \\
\text { the observed number of cholera cases increases, } \\
\text { thereby providing early notification of } \\
\text { the epidemic. } \\
\text { Added support to the hypothesis that } \\
\text { environmental forces influence the trigger of a } \\
\text { cholera outbreak. }\end{array}$ \\
\hline Perez-Saez et al., 2017 [58] & $\begin{array}{l}\text { Proposed a probabilistic spatial model to } \\
\text { investigate the role human mobility plays in } \\
\text { cholera transmission. }\end{array}$ & $\begin{array}{l}\text { With respect to cholera risk, highly populated } \\
\text { urban centers are more sensitive to El } \\
\text { Niño/Southern Oscillation than } \\
\text { rural periphery. } \\
\text { Cholera risk is largely transmitted from a } \\
\text { climate-sensitive core to the periphery. } \\
\text { Included human mobility as a model parameter } \\
\text { to improve outbreak prediction performance. }\end{array}$ \\
\hline
\end{tabular}

\section{Discussion}

Climate variability has had a dramatic impact on marine animal and plant communities, as well as marine prokaryotes, all of which play fundamental roles in maintaining life on Earth. Over the past half-century, changes in precipitation and temperature [104] have promoted the emergence and re-emergence of infectious diseases globally [105]. The Fourth Assessment Report of the Intergovernmental Panel on Climate Change (IPCC) suggested that the world will experience enhanced climate variability, including longterm increases in precipitation, temperature, and the number of extreme events, including droughts, floods, hurricanes, and tornadoes [106]. The complex interactions between and among various environmental conditions influence the ecological niche of disease agents. For example, a number of studies have documented a pattern of poleward spreading of $V$. cholerae, demonstrating geographic expansion [21,107-109]. Historically, only V. cholerae serogroup $\mathrm{O} 1$ was associated with pandemic cholera. However, non-O1 V. cholerae are causative agents of sporadic, yet significant, infections ranging in severity from mild to life-threatening. It has recently been reported that $V$. cholerae non-O1 infections are on the rise and represent one of the most striking examples of emerging human diseases linked to climate change [109].

On both local and global scales, climate variability has the potential to significantly affect the emergence, distribution, and prevalence of infectious disease agents and thereby impose a significant burden on public health [110]. One such observation was the massive cholera outbreak in Haiti during the months following Hurricane Matthew [9]. More recently, a cholera outbreak occurred in Yemen following civil unrest in 2016. Cholera appears to be transitioning towards endemicity in that country. In both Haiti and Yemen, cholera occurred during anomalously high temperatures and precipitation, lending support 
to the trigger hypothesis. Despite the advances made to date, an effective cholera predictive modeling system capable of effectively capturing the transmission of disease through compartmental models has yet to be developed. The transition of cholera from epidemic to endemic in Haiti and Yemen underscores the urgent need for environmental quantitative risk models. On a global scale, it will be necessary for future models to incorporate comparative data baselines with real-time data to improve model output and prediction.

Since it is now well established that $V$. cholerae is ubiquitous in the aquatic environment and plays a critical role in nutrient cycling and in environmental homeostasis, cholera cannot be eradicated, but it can be successfully controlled. Predictive models for cholera risk assessment will be critical in the future to safeguard public health. There is much greater interest in predictive modeling, and the transmission components of such models are receiving greater attention. However, emphasis on trigger components is needed to improve our understanding of the dynamics and progression of cholera. Trigger components have been described that improve quantitative risk modeling as well as disease intervention measures. Yet, most studies of cholera transmission are mechanistic and employ compartmental models, namely the susceptible-exposed-infectious-recovered model. The limitation of mechanistically driven compartmental models is their inability to quantify the uncertainty associated with the spread of cholera. The evolution of the quantitative risk modeling associated with the trigger module is highly promising, but greater success is expected with improved transmission modeling for quantitative risk prediction. With new information from satellite remote sensing, a comprehensive transmission component for the reliable and timely prediction of cholera will surely be available in the near future.

Author Contributions: Conceptualization: M.U., K.D.B., Y.J., A.J., A.H. and R.R.C.; Methodology: M.U., K.D.B. and Y.J.; Software: M.U., K.D.B. and Y.J.; Validation: M.U., K.D.B. and Y.J.; Formal Analysis: M.U., K.D.B. and Y.J.; Investigation: M.U., K.D.B. and Y.J.; Resources: A.J., A.H. and R.R.C.; Data Curation: M.U., K.D.B. and Y.J.; Writing-Original Draft Preparation: M.U., K.D.B. and Y.J.; Writing-Review and Editing: M.U., K.D.B., Y.J., A.J., A.H. and R.R.C.; Visualization: M.U., K.D.B. and Y.J.; Supervision: A.J., A.H. and R.R.C.; Project Administration: M.U., K.D.B., Y.J., A.J., A.H. and R.R.C.; Funding Acquisition: A.J., A.H. and R.R.C. All authors have read and agreed to the published version of the manuscript.

Funding: This research was funded by the National Institute of Environmental Health Sciences, National Institutes of Health (NIH)under award number R01ES030317A and the National Science Foundation (NSF) under award number OCE1839171 to Anwar Huq and Rita Colwell (University of Maryland, College Park, MD) with Antarpreet Jutla (University of Florida, Gainesville, FL). Further support was supplied by NSF under award number CCF1918749 to Rita Colwell. Colwell and Jutla gratefully acknowledge support from NASA award 80NSSC20K0814.

Conflicts of Interest: The sponsors had no role in the design, execution, interpretation, or writing of the study.

\section{References}

1. Oprea, M.; Njamkepo, E.; Cristea, D.; Zhukova, A.; Clark, C.G.; Kravetz, A.N.; Monakhova, E.; Ciontea, A.S.; Cojocaru, R.; Rauzier, J.; et al. The seventh pandemic of cholera in Europe revisited by microbial genomics. Nat. Commun. 2020, $11,5347$. [CrossRef] [PubMed]

2. Colwell, R.R. Global Climate and Infectious Disease: The Cholera Paradigm. Science 1996, 274, 2025-2031. [CrossRef]

3. Cholera. Available online: https://www.who.int/news-room/fact-sheets/detail/cholera (accessed on 29 June 2021).

4. Ali, M.; Nelson, A.R.; Lopez, A.L.; Sack, D.A. Updated global burden of cholera in endemic countries. PLoS Negl. Trop. Dis. 2015, 9, e0003832. [CrossRef] [PubMed]

5. Jutla, A.S.; Akanda, A.S.; Islam, S. Tracking Cholera in Coastal Regions using Satellite Observations. J. Am. Water Resour. Assoc. 2010, 46, 651-662. [CrossRef]

6. WHO; UNICEF. Progress on Sanitation and Drinking Water: 2010 Update; WHO: Geneva, Switzerland; UNICEF: New York, NY, USA, 2010. Available online: https:/ / www.who.int/water_sanitation_he (accessed on 5 June 2021).

7. Griffith, D.C.; Kelly-Hope, L.A.; Miller, M.A. Review of reported cholera outbreaks worldwide, 1995-2005. Am. J. Trop. Med. Hyg. 2006, 75, 973-977. [CrossRef] [PubMed]

8. Huq, A.; Colwell, R. Vibrios in the marine and estuarine environment: Tracking Vibrio cholerae. Ecosyst. Health 1996, 2, $198-214$. 
9. Khan, R.; Anwar, R.; Akanda, S.; McDonald, M.D.; Huq, A.; Jutla, A.; Colwell, R. Assessment of Risk of Cholera in Haiti following Hurricane Matthew. Am. J. Trop. Med. Hyg. 2017, 97, 896-903. [CrossRef] [PubMed]

10. Connolly, M.A.; Heymann, D.L. Deadly comrades: War and infectious diseases. Lancet 2002, 360, s23-s24. [CrossRef]

11. Federspiel, F.; Ali, M. The cholera outbreak in Yemen: Lessons learned and way forward. BMC Public Health 2018, $18,1338$. [CrossRef]

12. Republic, S.A. WHO Alliance for the Global Elimination of Trachoma by 2020: Progress report on elimination of trachoma, 2014-2016. Relev. Epidemiol. Hebd. 2017, 92, 359-368.

13. Camacho, A.; Bouhenia, M.; Alyusfi, R.; Alkohlani, A.; Naji, M.A.M.; de Radiguès, X.; Abubakar, A.M.; Almoalmi, A.; Seguin, C.; Sagrado, M.J.; et al. Cholera epidemic in Yemen, 2016-2018: An analysis of surveillance data. Lancet. Glob. Health 2018, 6, e680-e690. [CrossRef]

14. Jutla, A.; Aldaach, H.; Billian, H.; Akanda, A.; Huq, A.; Colwell, R. Satellite Based Assessment of Hydroclimatic Conditions Related to Cholera in Zimbabwe. PLoS ONE 2015, 10, e0137828. [CrossRef]

15. Jutla, A.; Whitcombe, E.; Hasan, N.; Haley, B.; Akanda, A.; Huq, A.; Alam, M.; Sack, R.B.; Colwell, R. Environmental factors influencing epidemic cholera. Am. J. Trop. Med. Hyg. 2013, 89, 597-607. [CrossRef] [PubMed]

16. Alam, M.; Hasan, N.A.; Sadique, A.; Bhuiyan, N.A.; Ahmed, K.U.; Nusrin, S.; Nair, G.B.; Siddique, A.K.; Sack, R.B.; Sack, D.A.; et al. Seasonal cholera caused by Vibrio cholerae serogroups O1 and O139 in the coastal aquatic environment of Bangladesh. Appl. Environ. Microbiol. 2006, 72, 4096-4104. [CrossRef] [PubMed]

17. Alam, M.; Islam, A.; Bhuiyan, N.A.; Rahim, N.; Hossain, A.; Khan, G.Y.; Ahmed, D.; Watanabe, H.; Izumiya, H.; Faruque, A.S.G.; et al. Clonal transmission, dual peak, and off-season cholera in Bangladesh. Infect. Ecol. Epidemiol. 2011, 1. [CrossRef]

18. Codeço, C.T. Endemic and epidemic dynamics of cholera: The role of the aquatic reservoir. BMC Infect. Dis. 2001, 1, 1. [CrossRef] [PubMed]

19. Huq, A.; Small, E.B.; West, P.A.; Huq, M.I.; Rahman, R.; Colwell, R.R. Ecological relationships between Vibrio cholerae and planktonic crustacean copepods. Appl. Environ. Microbiol. 1983, 45, 275-283. [CrossRef]

20. Almagro-Moreno, S.; Taylor, R.K. Cholera: Environmental Reservoirs and Impact on Disease Transmission. Microbiol. Spectr. 2013, 1. [CrossRef]

21. Vezzulli, L.; Grande, C.; Reid, P.C.; Hélaouët, P.; Edwards, M.; Höfle, M.G.; Brettar, I.; Colwell, R.R.; Pruzzo, C. Climate influence on Vibrio and associated human diseases during the past half-century in the coastal North Atlantic. Proc. Natl. Acad. Sci. USA 2016, 113, E5062-E5071. [CrossRef]

22. Vezzulli, L.; Pezzati, E.; Brettar, I.; Höfle, M.; Pruzzo, C. Effects of Global Warming on Vibrio Ecology. Microbiol. Spectr. 2015, 3. [CrossRef]

23. Constantin de Magny, G.; Murtugudde, R.; Sapiano, M.R.P.; Nizam, A.; Brown, C.W.; Busalacchi, A.J.; Yunus, M.; Nair, G.B.; Gil, A.I.; Lanata, C.F.; et al. Environmental signatures associated with cholera epidemics. Proc. Natl. Acad. Sci. USA 2008, 105, 17676-17681. [CrossRef] [PubMed]

24. Pollitzer, R. Cholera studies. 1. History of the disease. Bull. World Health Organ. 1954, 10, 421-461. [PubMed]

25. Hasan, J.A.; Bernstein, D.; Huq, A.; Loomis, L.; Tamplin, M.L.; Colwell, R.R. Cholera DFA: An improved direct fluorescent monoclonal antibody staining kit for rapid detection and enumeration of Vibrio cholerae O1. FEMS Microbiol. Lett. 1994, 120, 143-148. [CrossRef] [PubMed]

26. Lowenhaupt, E.; Huq, A.; Colwell, R.R.; Adingra, A.; Epstein, P.R. Rapid detection of Vibrio cholerae O1 in west Africa. Lancet 1998, 351, 34. [CrossRef]

27. Fykse, E.M.; Skogan, G.; Davies, W.; Olsen, J.S.; Blatny, J.M. Detection of Vibrio cholerae by real-time nucleic acid sequence-based amplification. Appl. Environ. Microbiol. 2007, 73, 1457-1466. [CrossRef]

28. Nandi, B.; Nandy, R.K.; Mukhopadhyay, S.; Nair, G.B.; Shimada, T.; Ghose, A.C. Rapid method for species-specific identification of Vibrio cholerae using primers targeted to the gene of outer membrane protein OmpW. J. Clin. Microbiol. 2000, 38, 4145-4151. [CrossRef]

29. Bauer, A.; Rørvik, L.M. A novel multiplex PCR for the identification of Vibrio vulnificus, Vibrio cholerae and Vibrio vulnificus. Lett. Appl. Microbiol. 2007, 45, 371-375. [CrossRef]

30. Hoshino, K.; Yamasaki, S.; Mukhopadhyay, A.K.; Chakraborty, S.; Basu, A.; Bhattacharya, S.K.; Nair, G.B.; Shimada, T.; Takeda, Y. Development and evaluation of a multiplex PCR assay for rapid detection of toxigenic Vibrio cholerae O1 and O139. FEMS Immunol. Med. Microbiol. 1998, 20, 201-207. [CrossRef] [PubMed]

31. Brumfield, K.D.; Carignan, B.M.; Ray, J.N.; Jumpre, P.E.; Son, M.S. Laboratory Techniques Used to Maintain and Differentiate Biotypes of Vibrio cholerae Clinical and Environmental Isolates. J. Vis. Exp. 2017. [CrossRef]

32. Thompson, F.L.; Swings, J. Taxonomy of the Vibrios. In The Biology of Vibrios; ASM Press: Washington, DC, USA, $2014 ;$ pp. 27-43.

33. Colwell, R.R.; Grimes, D.J. Nonculturable Microorganisms in the Environment; Springer: Boston, MA, USA, 2000; ISBN 978-1-4757-0273-6. [CrossRef]

34. Oliver, J.D. Recent findings on the viable but nonculturable state in pathogenic bacteria. FEMS Microbiol. Rev. 2010, 34, 415-425. [CrossRef]

35. Colwell, R.R. Viable but nonculturable bacteria: A survival strategy. J. Infect. Chemother. 2000, 6, 121-125. [CrossRef]

36. Colwell, R.R.; Brayton, P.; Herrington, D.; Tall, B.; Huq, A.; Levine, M.M. Viable but non-culturable Vibrio cholerae O1 revert to a cultivable state in the human intestine. World J. Microbiol. Biotechnol. 1996, 12, 28-31. [CrossRef] 
37. Senoh, M.; Ghosh-Banerjee, J.; Ramamurthy, T.; Colwell, R.R.; Miyoshi, S.-I.; Nair, G.B.; Takeda, Y. Conversion of viable but nonculturable enteric bacteria to culturable by co-culture with eukaryotic cells. Microbiol. Immunol. 2012, 56, 342-345. [CrossRef]

38. Alam, M.; Sultana, M.; Nair, G.B.; Siddique, A.K.; Hasan, N.A.; Sack, R.B.; Sack, D.A.; Ahmed, K.U.; Sadique, A.; Watanabe, H.; et al. Viable but nonculturable Vibrio cholerae $\mathrm{O} 1$ in biofilms in the aquatic environment and their role in cholera transmission. Proc. Natl. Acad. Sci. USA 2007, 104, 17801-17806. [CrossRef] [PubMed]

39. Colwell, R.R.; Spira, W.M. Cholera; Barua, D., Greenough, W.B., Eds.; Springer: Boston, MA, USA, 1992; ISBN 978-1-4757-9690-2. [CrossRef]

40. Huq, A.; Xu, B.; Chowdhury, M.A.; Islam, M.S.; Montilla, R.; Colwell, R.R. A simple filtration method to remove planktonassociated Vibrio cholerae in raw water supplies in developing countries. Appl. Environ. Microbiol. 1996, 62, 2508-2512. [CrossRef] [PubMed]

41. Colwell, R.R.; Huq, A.; Islam, M.S.; Aziz, K.M.A.; Yunus, M.; Khan, N.H.; Mahmud, A.; Sack, R.B.; Nair, G.B.; Chakraborty, J.; et al. Reduction of cholera in Bangladeshi villages by simple filtration. Proc. Natl. Acad. Sci. USA 2003, 100, 1051-1055. [CrossRef]

42. Cash, R.A.; Music, S.I.; Libonati, J.P.; Snyder, M.J.; Wenzel, R.P.; Hornick, R.B. Response of Man to Infection with Vibrio cholerae. I. Clinical, Serologic, and Bacteriologic Responses to a Known Inoculum. J. Infect. Dis. 1974, 129, 45-52. [CrossRef]

43. Silva-Valenzuela, C.A.; Camilli, A. Niche adaptation limits bacteriophage predation of Vibrio cholerae in a nutrient-poor aquatic environment. Proc. Natl. Acad. Sci. USA 2019, 116, 1627-1632. [CrossRef] [PubMed]

44. Faruque, S.M.; Mekalanos, J.J. Phage-bacterial interactions in the evolution of toxigenic Vibrio cholerae. Virulence 2012, 3, 556-565. [CrossRef] [PubMed]

45. Vezzulli, L.; Guzmán, C.A.; Colwell, R.R.; Pruzzo, C. Dual role colonization factors connecting Vibrio cholerae's lifestyles in human and aquatic environments open new perspectives for combating infectious diseases. Curr. Opin. Biotechnol. 2008, 19, 254-259. [CrossRef] [PubMed]

46. McFall-Ngai, M. Divining the Essence of Symbiosis: Insights from the Squid-Vibrio Model. PLoS Biol. 2014, 12, e1001783. [CrossRef]

47. Martínez, J.L. Bacterial pathogens: From natural ecosystems to human hosts. Environ. Microbiol. 2013, 15, 325-333. [CrossRef]

48. Mavian, C.; Paisie, T.K.; Alam, M.T.; Browne, C.; de Rochars, V.M.B.; Nembrini, S.; Cash, M.N.; Nelson, E.J.; Azarian, T.; Ali, A.; et al. Toxigenic Vibrio cholerae evolution and establishment of reservoirs in aquatic ecosystems. Proc. Natl. Acad. Sci. USA 2020, 117, 7897-7904. [CrossRef]

49. Hasan, N.A.; Choi, S.Y.; Eppinger, M.; Clark, P.W.; Chen, A.; Alam, M.; Haley, B.J.; Taviani, E.; Hine, E.; Su, Q.; et al. Genomic diversity of 2010 Haitian cholera outbreak strains. Proc. Natl. Acad. Sci. USA 2012, 109, E2010-E2017. [CrossRef] [PubMed]

50. Conner, J.G.; Teschler, J.K.; Jones, C.J.; Yildiz, F.H. Staying Alive: Vibrio cholerae's Cycle of Environmental Survival, Transmission, and Dissemination. Microbiol. Spectr. 2016, 4. [CrossRef]

51. Meibom, K.L.; Blokesch, M.; Dolganov, N.A.; Wu, C.-Y.; Schoolnik, G.K. Chitin induces natural competence in Vibrio cholerae. Science 2005, 310, 1824-1827. [CrossRef] [PubMed]

52. Ceccarelli, D.; Chen, A.; Hasan, N.A.; Rashed, S.M.; Huq, A.; Colwell, R.R. Non-O1/non-O139 Vibrio cholerae carrying multiple virulence factors and V. cholerae O1 in the Chesapeake Bay, Maryland. Appl. Environ. Microbiol. 2015, 81, 1909-1918. [CrossRef] [PubMed]

53. Carignan, B.M.; Brumfield, K.D.; Son, M.S. Single Nucleotide Polymorphisms in Regulator-Encoding Genes Have an Additive Effect on Virulence Gene Expression in a Vibrio cholerae Clinical Isolate. Msphere 2016, 1, e00253-16. [CrossRef]

54. Blokesch, M.; Schoolnik, G.K. Serogroup Conversion of Vibrio cholerae in Aquatic Reservoirs. PLoS Pathog. 2007, 3, e81. [CrossRef] [PubMed]

55. Colwell, R.R.; Huq, A.; Chowdhury, M.A.; Brayton, P.R.; Xu, B. Serogroup conversion of Vibrio cholerae. Can. J. Microbiol. 1995, 41, 946-950. [CrossRef] [PubMed]

56. Baracchini, T.; King, A.A.; Bouma, M.J.; Rodó, X.; Bertuzzo, E.; Pascual, M. Seasonality in cholera dynamics: A rainfall-driven model explains the wide range of patterns in endemic areas. Adv. Water Resour. 2017, 108, 357-366. [CrossRef]

57. Martinez, P.P.; Reiner, R.C.; Cash, B.A.; Rodó, X.; Shahjahan Mondal, M.; Roy, M.; Yunus, M.; Faruque, A.S.G.; Huq, S.; King, A.A.; et al. Cholera forecast for Dhaka, Bangladesh, with the 2015-2016 El Niño: Lessons learned. PLoS ONE 2017, 12, e0172355. [CrossRef] [PubMed]

58. Perez-Saez, J.; King, A.A.; Rinaldo, A.; Yunus, M.; Faruque, A.S.G.; Pascual, M. Climate-driven endemic cholera is modulated by human mobility in a megacity. Adv. Water Resour. 2017, 108, 367-376. [CrossRef]

59. Deen, J.; Mengel, M.A.; Clemens, J.D. Epidemiology of cholera. Vaccine 2020, 38 (Suppl. 1), A31-A40. [CrossRef]

60. Glass, R.I.; Becker, S.; Huq, M.I.; Stoll, B.J.; Khan, M.U.; Merson, M.H.; Lee, J.V.; Black, R.E. Endemic cholera in rural Bangladesh, 1966-1980. Am. J. Epidemiol. 1982, 116, 959-970. [CrossRef]

61. Shears, P. Recent developments in cholera. Curr. Opin. Infect. Dis. 2001, 14, 553-558. [CrossRef] [PubMed]

62. Akanda, A.S.; Jutla, A.S.; Islam, S. Dual peak cholera transmission in Bengal Delta: A hydroclimatological explanation. Geophys. Res. Lett. 2009, 36, L19401. [CrossRef]

63. Lattos, A.; Bitchava, K.; Giantsis, I.A.; Theodorou, J.A.; Batargias, C.; Michaelidis, B. The implication of Vibrio bacteria in the winter mortalities of the critically endangered pinna nobilis. Microorganisms 2021, 9, 922. [CrossRef] [PubMed]

64. Baker-Austin, C.; Stockley, L.; Rangdale, R.; Martinez-Urtaza, J. Environmental occurrence and clinical impact of Vibrio vulnificus and Vibrio vulnificus: A European perspective. Environ. Microbiol. Rep. 2010, 2, 7-18. [CrossRef] 
65. Ceccarelli, D.; Colwell, R.R. Vibrio ecology, pathogenesis, and evolution. Front. Microbiol. 2014, 5. [CrossRef]

66. Thompson, J.R.; Polz, M.F. Dynamics of Vibrio Populations and Their Role in Environmental Nutrient Cycling. In The Biology of Vibrios; ASM Press: Washington, DC, USA, 2014; pp. 190-203. [CrossRef]

67. Lobitz, B.; Beck, L.; Huq, A.; Wood, B.; Fuchs, G.; Faruque, A.S.G.; Colwell, R. Climate and infectious disease: Use of remote sensing for detection of Vibrio cholerae by indirect measurement. Proc. Natl. Acad. Sci. USA 2000, 97, 1438-1443. [CrossRef]

68. Emch, M.; Feldacker, C.; Yunus, M.; Streatfield, P.K.; DinhThiem, V.; Canh, D.G.; Ali, M. Local environmental predictors of cholera in Bangladesh and Vietnam. Am. J. Trop. Med. Hyg. 2008, 78, 823-832. [CrossRef] [PubMed]

69. Xu, M.; Cao, C.X.; Wang, D.C.; Kan, B.; Xu, Y.F.; Ni, X.L.; Zhu, Z.C. Environmental factor analysis of cholera in China using remote sensing and geographical information systems. Epidemiol. Infect. 2016, 144, 940-951. [CrossRef]

70. Jutla, A.S.; Akanda, A.S.; Islam, S. A framework for predicting endemic cholera using satellite derived environmental determinants. Environ. Model. Softw. 2013, 47, 148-158. [CrossRef]

71. Kirpich, A.; Weppelmann, T.A.; Yang, Y.; Ali, A.; Morris, J.G.; Longini, I.M. Cholera Transmission in Ouest Department of Haiti: Dynamic Modeling and the Future of the Epidemic. PLoS Negl. Trop. Dis. 2015, 9, e0004153. [CrossRef] [PubMed]

72. Eisenberg, M.C.; Kujbida, G.; Tuite, A.R.; Fisman, D.N.; Tien, J.H. Examining rainfall and cholera dynamics in Haiti using statistical and dynamic modeling approaches. Epidemics 2013, 5, 197-207. [CrossRef]

73. Jutla, A.; Akanda, A.; Unnikrishnan, A.; Huq, A.; Colwell, R. Predictive Time Series Analysis Linking Bengal Cholera with Terrestrial Water Storage Measured from Gravity Recovery and Climate Experiment Sensors. Am. J. Trop. Med. Hyg. 2015, 93, 1179-1186. [CrossRef] [PubMed]

74. Huq, A.; West, P.A.; Small, E.B.; Huq, M.I.; Colwell, R.R. Influence of water temperature, salinity, and pH on survival and growth of toxigenic Vibrio cholerae serovar 01 associated with live copepods in laboratory microcosms. Appl. Environ. Microbiol. 1984, 48, 420-424. [CrossRef]

75. Singleton, F.L.; Attwell, R.; Jangi, S.; Colwell, R.R. Effects of temperature and salinity on Vibrio cholerae growth. Appl. Environ. Microbiol. 1982, 44, 1047-1058. [CrossRef] [PubMed]

76. Khan, R.; Nguyen, T.H.; Shisler, J.; Lin, L.-S.; Jutla, A.; Colwell, R.R. Evaluation of Risk of Cholera after a Natural Disaster: Lessons Learned from the 2015 Nepal Earthquake. J. Water Resour. Plan. Manag. 2018, 144, 04018044. [CrossRef]

77. Heesterbeek, H.; Anderson, R.M.; Andreasen, V.; Bansal, S.; De Angelis, D.; Dye, C.; Eames, K.T.D.; Edmunds, W.J.; Frost, S.D.W.; Funk, S.; et al. Modeling infectious disease dynamics in the complex landscape of global health. Science 2015, 347, aaa4339. [CrossRef] [PubMed]

78. Chowell, G.; Sattenspiel, L.; Bansal, S.; Viboud, C. Mathematical models to characterize early epidemic growth: A review. Phys. Life Rev. 2016, 18, 66-97. [CrossRef]

79. Andrews, J.R.; Basu, S. Transmission dynamics and control of cholera in Haiti: An epidemic model. Lancet 2011, 377, 1248-1255. [CrossRef]

80. Grad, Y.H.; Miller, J.C.; Lipsitch, M. Cholera modeling: Challenges to quantitative analysis and predicting the impact of interventions. Epidemiology 2012, 23, 523-530. [CrossRef] [PubMed]

81. Brauer, F. Compartmental Models in Epidemiology BT-Mathematical Epidemiology; Brauer, F., van den Driessche, P., Wu, J., Eds.; Springer: Berlin/Heidelberg, Germany, 2008; pp. 19-79, ISBN 978-3-540-78911-6. [CrossRef]

82. Lemos-Paião, A.P.; Silva, C.J.; Torres, D.F.M. A cholera mathematical model with vaccination and the biggest outbreak of world's history. AIMS Math. 2019, 3, 448-463. [CrossRef]

83. Wang, X.; Gao, D.; Wang, J. Influence of human behavior on cholera dynamics. Math. Biosci. 2015, 267, 41-52. [CrossRef] [PubMed]

84. Meszaros, V.A.; Miller-Dickson, M.D.; Baffour-Awuah, F.; Almagro-Moreno, S.; Ogbunugafor, C.B. Direct transmission via households informs models of disease and intervention dynamics in cholera. PLoS ONE 2020, 15, e0229837. [CrossRef]

85. Abrams, J.Y.; Copeland, J.R.; Tauxe, R.V.; Date, K.A.; Belay, E.D.; Mody, R.K.; Mintz, E.D. Real-time modelling used for outbreak management during a cholera epidemic, Haiti, 2010-2011. Epidemiol. Infect. 2013, 141, 1276-1285. [CrossRef]

86. Che, E.N.; Kang, Y.; Yakubu, A.-A. Risk structured model of cholera infections in Cameroon. Math. Biosci. 2020, $320,108303$. [CrossRef] [PubMed]

87. Dangbé, E.; Irépran, D.; Perasso, A.; Békollé, D. Mathematical modelling and numerical simulations of the influence of hygiene and seasons on the spread of cholera. Math. Biosci. 2018, 296, 60-70. [CrossRef]

88. Glass, R.I.; Svennerholm, A.M.; Khan, M.R.; Huda, S.; Imdadul Huq, M.; Holmgren, J. Seroepidemiological studies of EI tor cholera in bangladesh: Association of serum antibody levels with protection. J. Infect. Dis. 1985, 151, 236-242. [CrossRef] [PubMed]

89. Chao, D.L.; Longini, I.M.; Morris, J.G. Modeling Cholera Outbreaks. In Cholera Outbreaks; Nair, G.B., Takeda, Y., Eds.; Springer: Berlin/Heidelberg, Germany, 2014; pp. 195-209. ISBN 978-3-642-55404-9. [CrossRef]

90. Ritter, A.S.; Chowdhury, F.; Franke, M.F.; Becker, R.L.; Bhuiyan, T.R.; Khan, A.I.; Saha, N.C.; Ryan, E.T.; Calderwood, S.B.; LaRocque, R.C.; et al. Vibriocidal titer and protection from cholera in children. Open Forum Infect. Dis. 2019, 6. [CrossRef]

91. Faruque, A.S.G.; Malek, M.A.; Khan, A.I.; Huq, S.; Salam, M.A.; Sack, D.A. Diarrhoea in elderly people: Aetiology, and clinical characteristics. Scand. J. Infect. Dis. 2004, 36, 204-208. [CrossRef] [PubMed]

92. Cassiers, T.; Kesteloot, C. Socio-spatial Inequalities and Social Cohesion in European Cities. Urban. Stud. 2012, 49, 1909-1924. [CrossRef] 
93. Najib, K. Socio-spatial inequalities and dynamics of rich and poor enclaves in three French cities: A policy of social mixing under test. Popul. Space Place 2020, 26. [CrossRef]

94. Gerometta, J.; Haussermann, H.; Longo, G. Social Innovation and Civil Society in Urban Governance: Strategies for an Inclusive City. Urban. Stud. 2005, 42, 2007-2021. [CrossRef]

95. Al-Arydah, M.; Mwasa, A.; Tchuenche, J.M.; Smith, R.J. Modeling cholera disease with education and chlorination. J. Biol. Syst. 2013, 21, 1340007. [CrossRef]

96. Einarsdóttir, J.; Passa, A.; Gunnlaugsson, G. Health education and cholera in rural Guinea-Bissau. Int. J. Infect. Dis. 2001, 5, 133-138. [CrossRef]

97. Koepke, A.A.; Longini, I.M., Jr.; Halloran, M.E.; Wakefield, J.; Minin, V.N. Predictive modeling of cholera outbreaks in Bangladesh. Ann. Appl. Stat. 2016, 10. [CrossRef] [PubMed]

98. Kulinkina, A.V.; Mohan, V.R.; Francis, M.R.; Kattula, D.; Sarkar, R.; Plummer, J.D.; Ward, H.; Kang, G.; Balraj, V.; Naumova, E.N. Seasonality of water quality and diarrheal disease counts in urban and rural settings in south India. Sci. Rep. 2016, 6, 20521. [CrossRef]

99. Altizer, S.; Dobson, A.; Hosseini, P.; Hudson, P.; Pascual, M.; Rohani, P. Seasonality and the dynamics of infectious diseases. Ecol. Lett. 2006, 9, 467-484. [CrossRef]

100. Ruiz-Moreno, D.; Pascual, M.; Bouma, M.; Dobson, A.; Cash, B. Cholera Seasonality in Madras (1901-1940): Dual Role for Rainfall in Endemic and Epidemic Regions. Ecohealth 2007, 4, 52-62. [CrossRef]

101. Nishiura, H.; Tsuzuki, S.; Yuan, B.; Yamaguchi, T.; Asai, Y. Transmission dynamics of cholera in Yemen, 2017: A real time forecasting. Theor. Biol. Med. Model. 2017, 14, 14. [CrossRef] [PubMed]

102. Predicting Cholera Risk in Yemen. Available online: https://earthobservatory.nasa.gov/images/147101/predicting-cholera-riskin-yemen (accessed on 5 June 2021).

103. van den Driessche, P. Reproduction numbers of infectious disease models. Infect. Dis. Model. 2017, 2, 288-303. [CrossRef] [PubMed]

104. Aguilar, E.; Peterson, T.C.; Obando, P.R.; Frutos, R.; Retana, J.A.; Solera, M.; Soley, J.; García, I.G.; Araujo, R.M.; Santos, A.R.; et al. Changes in precipitation and temperature extremes in Central America and northern South America, 1961-2003. J. Geophys. Res. Atmos. 2005, 110, 1-15. [CrossRef]

105. El-Sayed, A.; Kamel, M. Climatic changes and their role in emergence and re-emergence of diseases. Environ. Sci. Pollut. Res. 2020, 27, 22336-22352. [CrossRef]

106. AR4 Climate Change 2007: The Physical Science Basis_IPCC. Available online: https://www.ipcc.ch/report/ar4/wg1/ (accessed on 29 June 2021).

107. Baker-Austin, C.; Trinanes, J.; Gonzalez-Escalona, N.; Martinez-Urtaza, J. Non-Cholera Vibrios: The Microbial Barometer of Climate Change. Trends Microbiol. 2017, 25, 76-84. [CrossRef]

108. Baker-Austin, C.; Trinanes, J.A.; Taylor, N.G.H.; Hartnell, R.; Siitonen, A.; Martinez-Urtaza, J. Emerging Vibrio risk at high latitudes in response to ocean warming. Nat. Clim. Chang. 2013, 3, 73-77. [CrossRef]

109. Vezzulli, L.; Baker-Austin, C.; Kirschner, A.; Pruzzo, C.; Martinez-Urtaza, J. Global emergence of environmental non-O1/O139 Vibrio cholerae infections linked with climate change: A neglected research field? Environ. Microbiol. 2020, 22, 4342-4355. [CrossRef]

110. Anderson, P.K.; Cunningham, A.A.; Patel, N.G.; Morales, F.J.; Epstein, P.R.; Daszak, P. Emerging infectious diseases of plants: Pathogen pollution, climate change and agrotechnology drivers. Trends Ecol. Evol. 2004, 19, 535-544. [CrossRef] 